\title{
The risk of cutaneous melanoma in melanocytic nevi
}

\author{
Risco de melanoma cutâneo nos nevos melanocíticos
}

\author{
Nurimar Conceição Fernandes ${ }^{1}$
}

\begin{abstract}
The data on melanoma associaed with melanocytic nevus are controversial. A longitudinal prospective study of 107 cases of cutaneous melanoma revealed that $9(8.4 \%)$ cases were presumed to be linked to a precursor lesion, but only in $1(0.9 \%)$ out of these cases the histopathological examination showed an associated melanocytic nevus. The vague information of a preexisting lesion of cutaneous melanoma is not sufficient to consider it a tumour precursor and it requires histopathological evidence to confirm the diagnosis.

Keywords: Epidemiology; Melanoma; Nevus, pigmented; Pathology; Prospective studies

Resumo: Os dados sobre risco de melanoma cutâneo nos nevos melanocíticos são ainda controversos. O estudo longitudinal prospectivo de 107 casos de melanoma cutâneo revelou que em 9/107 casos (8,4\%) houve presunção de lesão precursora, porém em $1 / 107$ caso $(0,9 \%)$ houve comprovação histopatológica para nevo melanocítico. A informação vaga de presença de lesão precursora do melanoma cutâneo torna vulnerável sua vinculação com o tumor e implica em comprovação histopatológica.

Palavras-chave: Epidemiologia; Estudos prospectivos; Melanoma; Nevo pigmentado; Patologia
\end{abstract}

The risk of malignant transformation in the congenital melanocytic nevi (CMN) generally ranges, according to the literature, from 5 to $40 \%$ and from 4.5 to $10 \% .^{1-3}$ The risk of developing melanoma in small $\mathrm{CMN}$ is more common in adults (around 60 years). ${ }^{4}$

The diagnosis of melanocytic nevus (congenital or acquired) is primarily clinical, and its presence at or immediately following birth is conclusive for the diagnosis of CMN. The acquired melanocytic nevi (AMN) arise from two years of age in the majority of cases, reaching a peak in the second and third decades and disappearing between the seventh and ninth decades. Its development seems to be related to some factors such as skin type, ethnicity, genetic predisposition and exposure to ultraviolet light. AMN tend to be more numerous in chronically sun-exposed areas and among children with light skin, blond hair and blue eyes. This pattern is not described for CMN. ${ }^{5}$ The histopathological examination of 1101 cutaneous melanomas has revealed that $23.3 \%$ have been associated with melanocytic nevi, $56.5 \%$ being histopathologically classified as AMN, $5.8 \%$ as $\mathrm{CMN}$, and $37.7 \%$ as dysplasic. ${ }^{6}$ In other large series it has been demonstrated by histopathological examination that small CMN have been the precursor to melanoma in $8.1 \%$ of cases. $^{7}$ Forty-four $(21.6 \%)$ of the total of 204 cases of melanoma have resulted from the transformation of small CMN, defined as based exclusively on anamnesis data. ${ }^{8}$

A longitudinal cross-sectional study of 107 cases of cutaneous melanoma in HUCFF/UFRJ between 1993 and 2008 revealed the four clinical and

Received on 11.01.2012.

Approved by the Advisory Board and accepted for publication on 25.06.2012.

* Study conducted in the Departments of Dermatology / Anatomic Pathology and Oncology, Clinic of the Clementino Fraga Filho University Hospital, Federal University of Rio de Janeiro (UFRJ) - Rio de Janeiro (RJ), Brazil.

Conflict of interest: None

Financial funding: None

PhD - Associate Professor at the Federal University of Rio de Janeiro (UFRJ) - Rio de Janeiro (RJ), Brazil.

(C2013 by Anais Brasileiros de Dermatologia 
TABLE 1: Distribution of cases according to clinical type

\begin{tabular}{ll} 
Clinical Type & No of cases \\
\hline Extensive superficial & 63 \\
Acral lentiginous & 23 \\
Nodular & 12 \\
Lentigo maligna & 9 \\
\hline Total & $\mathbf{1 0 7}$
\end{tabular}

eight histopathological types (Tables 1 and 2).,90

In nine $(8.4 \%)$ of the total of 107 cases, a precursor lesion was reported compatible with melanocytic nevi - in eight cases since childhood; in one case there was no information on the length of time it took to evolve. The histopathological types of these cases were defined as superficial spreading (4), nodular (2), desmoplastic (1), unclassified (1), histologically associated to nevus (01).

The dimensions of the melanoma discarded $\mathrm{CMN}$ of medium, large, and giant sizes, remaining the definition of small CMN $(<1.5 \mathrm{~cm})$ and AMN. ${ }^{5}$ The
TABLE 2: Distribution of cases according to histopathological type

\begin{tabular}{ll}
\hline Histopathological Type & No of cases \\
\hline Extensive superficial & 31 \\
In situ & 24 \\
Nodular & 15 \\
Lentigo maligna & 8 \\
Acral lentiginous & 5 \\
Desmoplasic & 2 \\
Amelanotic & 1 \\
Associated with melanocytic nevus & $1(0.9 \%)$ \\
Not classified & 20 \\
\hline Total & $\mathbf{1 0 7}$ \\
\hline
\end{tabular}

presented data allow the conclusion that the association between melanocytic nevus and melanoma should be confirmed by histopathology. The possible total occupancy of the melanocytic nevi by neoplastic cells imposes itself as a variable in the study of the magnitude of the risk of transforming melanocytic nevi into melanoma.

\section{REFERENCES}

1. Togawa Y, Nakamura Y, Kamada N, Kambe N, Takahashi Y, Matsue H. Melanoma in association with acquired melanocytic nevus in Japan: a review of cases in the literature. Int J Dermatol. 2010;49:1362-7.

2. Tannous ZS, Mihm MC Jr, Sober AJ, Duncan LM. Congenital melanocytic nevi: clinical and histopathological features, risk of melanoma, and clinical management. J Am Acad Dermatol. 2005;52:197-203.

3. Marghoob AA. Congenital melanocytic nevi: evaluation and management. Dermatol Clin. 2002;20:607-16.

4. Schaffer JV. Pigmented lesions in children: when to worry. Curr Open Pediatric. 2007;19:430-40.

5. Fernandes NC, Machado JLR. Estudo clínico dos nevos melanocíticos congênitos na criança e adolescente. An Bras Dermatol. 2009;84:129-35.

6. Marks R, Dorevitch AP, Mason G. Do all melanomas come from "moles" ? A study of histological association between melanocytic naevi and melanoma. Australasian J Dermatol. 1990;31:77-80.

7. Rhodes AR, Melski JW. Small congenital nevocellular nevi and the risk of cutaneous melanoma. J Pediatr. 1982;100:219-24.

8. Maia M, Russo C, Ferrari N, Jorge D, Ribeiro MCSA, Müller H, et al. Relação entre o nevo melanocítico congênito pequeno e o melanoma cutâneo. An Bras Dermatol. 2003;78:189-95
9. Fernandes NC, Calmon R, Maceira JP, Cuzzi T, da Silva CSC. Melanoma cutâneo: estudo prospectivo de 65 casos. An Bras Dermatol. 2005;80:25-34.

10. Fernandes NC, Calmon R. Melanoma cutâneo: estudo prospectivo de 42 casos. An Bras Dermatol. 2011;86:375-7.
MAILING ADDRESS:

Nurimar Conceição Fernandes

Rua Alexandre de Gusmão, 28 - 201

20520-120 Rio de Janeiro, RJ.

Brazil

E-mail:nurimarfernandes@terra.com.br

How to cite this article: Fernandes NC. The risk of cutaneous melanoma in melanocytic nevi. An Bras Dermatol. 2013;88(2):314-5 